\title{
Árangur fleyg- og geiraskurða við lungnakrabbameini á Íslandi
}

\author{
Ásgeir Alexandersson læknanemi ${ }^{1}$, Steinn Jónsson læknir,2, Helgi J. Ísaksson meinafræðingur³, Tómas Guðbjartsson læknir,4
}

\section{ÁGRIP}

Inngangur: Hefðbundin aðgerð við lungnakrabbameini öðru en smáfrumukrabbameini er blaðnám. Í völdum tilvikum, einkum pegar lungnastarfsemi er mikið skert, er gripið til fleyg- eða geiraskurðar. Markmið pessarar rannsóknar var að kanna árangur pessara aðgerða hér á landi.

Efniviður og aðferðir: Afturskyggn rannsókn á sjúklingum sem gengust undir fleyg- eða geiraskurð vegna lungnakrabbameins af öðrum toga en smáfrumukrabbameini á Íslandi 1994-2008. Kannaðar voru ábendingar aðgerðar, stigun eftir aðgerð, fylgikvillar og heildarlífshorfur. Öll vefjasýni voru endurskoðuð.

Niðurstöður: Alls gengust 44 sjúklingar (52,3\% konur) undir samtals 47 fleyg- eða geiraskurði. Meðalaldur var 69,1 ár og greindust 38,3\% tilfella fyrir tilviljun. Saga um kransæðasjúkdóm (55,3\%) og langvinn lungnateppa (40,4\%) voru algengustu áhættupættirnir og meðal ASA-skor var 2,6. Aðgerðirnar tóku að meðaltali 83 mínútur (bil 30-131) og miðgildi legutíma var 9 dagar (bil 4-24). Helstu fylgikvillar voru lungnabólga (14,9\%) og langvarandi loftleki (12,8\%). Tveir sjúklingar fengu alvarlegan fylgikvilla en enginn lést innan 30 daga frá aðgerð. Meðalstærð æxlanna var 2,3 cm (bil 0,8-5,0) og var kirtilmyndandi krabbamein (66,7\%) algengasta vefjagerðin. Stigun eftir aðgerð sýndi að 78,7\% tilfella voru á stigi IA/IB, 17,0\% á stigi IIA/IIB og tveir á stigi IIIA. Eins árs og 5 ára lífshorfur voru $85,1 \%$ og $40,9 \%$.

Ályktun: Lífshorfur eftir fleyg- og geiraskurði á Íslandi eru góðar og tíđni fylgikvilla lág. Pessar niðurstöður eru svipaðar og sést hafa eftir blaðnám hér á landi pótt hátt hlutfall pessara sjúklinga hafi pekkta hjarta- og æðasjúkdóma og skerta lungnastarfsemi.

${ }^{1}$ Læknadeild HÍ, 2lungnadeild ${ }^{3}$ rannsóknarstofu í meinafræði, ${ }^{4}$ hjartaog lungnaskurðdeild Landspítala.

\section{Fyrirspurnir:} Tómas Guðbjartsson tomasgud@landspitali.is

Barst: 31. desember 2010, - sambykkt til birtingar: 9. april 2011

Höfundar tiltaka engin hagsmunatengsl.

\section{Inngangur}

Lungnakrabbamein er næstalgengasta krabbameinið á Íslandi og pað krabbamein sem dregur flesta til dauða. ${ }^{1}$ Skurðaðgerð er helsta læknandi meðferðin hjá sjúklingum með lungnakrabbamein önnur en smáfrumukrabbamein (ÖES). ${ }^{2,3}$ Hlutfall sjúklinga sem gengst undir aðgerð er aðeins $25-30 \%{ }^{4}$ og felst hefðbundin meðferð í blaðnámi par sem lungnablað er fjarlægt í heild sinni. ${ }^{2,5}$ Í tilvikum par sem sjúklingar eru ekki taldir pola blaðnám vegna skertrar lungnastarfsemi eða annarra undirliggjandi sjúkdóma er stundum hægt að framkvæma fleyg- eða geiraskurð. ${ }^{2}$ Í fleygskurði er heftibyssa notuð til að fjarlægja fleyg úr lungnavefnum. Svipuð tækni er notuð við geiraskurð en pá er lungnageiri fjarlægður í heild sinni. ${ }^{6}$ Fleyg- og geiraskurðir taka styttri tíma, eru tæknilega einfaldari og meira er varðveitt af lungnavef en við blaðnám. , $7^{7}$ Ekki eru til staðlaðar leiðbeiningar um hvenær skuli framkvæma fleyg- og geiraskurði. Pessar aðgerðir eru pó taldir síðri kostir en blaðnám hvað lækningu varðar ${ }^{2}$ par sem tíðni endurtekins krabbameins er allt að prefalt hærri eftir fyrrnefndu aðgerðirnar. ${ }^{5}$ Skýringin er talin vera sú að eitlar miðsvæðis í lungnablaðinu (N1-eitlar) eru oftar fjarlægðir við blaðnám en fleyg- eða geiraskurð, en pessir eitlar geta í allt að $15 \%$ tilfella innihaldið meinvörp. ${ }^{2,} 8$ Í nýlegum rannsóknum hefur pó verið sýnt fram á að við meðferð smárra T1 æxla $(<2 \mathrm{~cm})$ eru lífshorfur sambærilegar eftir geiraskurði og blaðnám. ${ }^{6,7,9}$ Fleyg- og geiraskurðir geta einnig átt við pegar lítil æxli hafa svokallað hélu-útlit (ground glass opacity) á tölvusneiðmynd (TS), en slík æxli vaxa sjaldan ífarandi. ${ }^{10}$

Á síðustu tveimur árum hafa birst í Læknablađinu tvær greinar um árangur blaðnáms hér á landi ${ }^{11,12}$ og ein um árangur lungnabrottnáms við lungnakrabbameini ÖES. ${ }^{13}$ Árangur fleyg- og geiraskurða hefur hins vegar ekki verið rannsakaður sérstaklega og var markmið pessarar rannsóknar að kanna árangur pessara aðgerða hér á landi. Sérstök áhersla var lögð á að kanna ábendingar aðgerða, fylgikvilla og lífshorfur og að bera niðurstöður saman við hinar íslensku rannsóknirnar.

\section{Efniviður og aðferðir}

Rannsóknin var afturskyggn og náði til allra sjúklinga á Íslandi sem gengust undir fleyg- eða geiraskurð við lungnakrabbameini ÖES frá 1. janúar 1994 til 31. desember 2008. Rannsóknin náði eingöngu til peirra sjúklinga par sem aðgerðin var gerð vegna frumæxlis í læknandi tilgangi. Sýnatökur og aðgerðir framkvæmdar í líknandi skyni voru pví ekki hafðar með.

Alls gengust 44 sjúklingar $(52,3 \%$ konur) undir samtals 47 aðgerðir á tímabilinu; 42 fleygskurði $(89,4 \%)$ og fimm geiraskurði (10,6\%). Prír sjúklingar gengust undir tvo fleygskurði, og var í öllum tilvikum um aðskilin frumæxli að ræða. Annar sjúklingur greindist með tvö frumæxli í mið- og efra blaði hægra lunga og voru bæði æxlin fjarlægð í sömu aðgerð. 
Tafla I. Klínískar upplýsingar um 44 sjúklinga fyrir aðgerð sem gengust undir 47 fleyg- eða geiraskurði við lungnakrabbameini öđru en smáfrumukrabbameini á Íslandi 1994-2008. Gefinn er upp fjöldi tilfella og prósentur í sviga. Prósentutölur miðast við 47 tilfelli en ekki sjúklinga. Öndunarmælingu vantaði í átta tilfellum.

\begin{tabular}{lc}
\hline Upplýsingar & $\boldsymbol{n}(\%)$ \\
\hline Saga um reykingar & $46(97,9)$ \\
\hline Langvinn lungnateppa & $19(40,4)$ \\
\hline FEV ${ }_{1}<75 \%$ af spáđu & $(41,0)$ \\
\hline FVC <75\% af spáđu & $(33,3)$ \\
\hline Kransæðasjúkdómur & $26(55,3)$ \\
\hline Saga um hjartsláttartruflanir & $8(17,0)$ \\
\hline ASA-flokkun:* & $2(4,3)$ \\
\hline I & $15(31,9)$ \\
\hline II & $29(61,7)$ \\
\hline III & $1(2,1)$ \\
\hline IV
\end{tabular}

Sjúklingagögn voru fengin úr tveimur aðskildum skrám, aðgerða- og greiningaskrám Landspítala og úr gagnagrunni rannsóknarstofu Landspítala í meinafræði. Fengnar voru upplýsingar úr Krabbameinsskrá Krabbameinsfélags Íslands um fjölda nýgreindra lungnakrabbameina ÖES á rannsóknartímabilinu og pannig reiknað hlutfall peirra sem fóru í pessar aðgerðir af öllum greindum tilfellum. Klínískar upplýsingar voru fengnar úr sjúkráskrám og öll vefjasýni skoðuð að nýju af tveimur höfunda (ÁA og HJÍ).

Úr sjúkraskrám voru skráđar rúmlega 80 breytur í tölvuforritið Excel, meðal annars einkenni, áhættupættir og ástand sjúklinga fyrir aðgerð, fylgikvillar eftir aðgerð og legutími. Skráð var ASAflokkun (American Society of Anesthesiologists) sjúklinga sem metur heilsufar og klínískt ástand sjúklings fyrir aðgerð ${ }^{14}$ auk

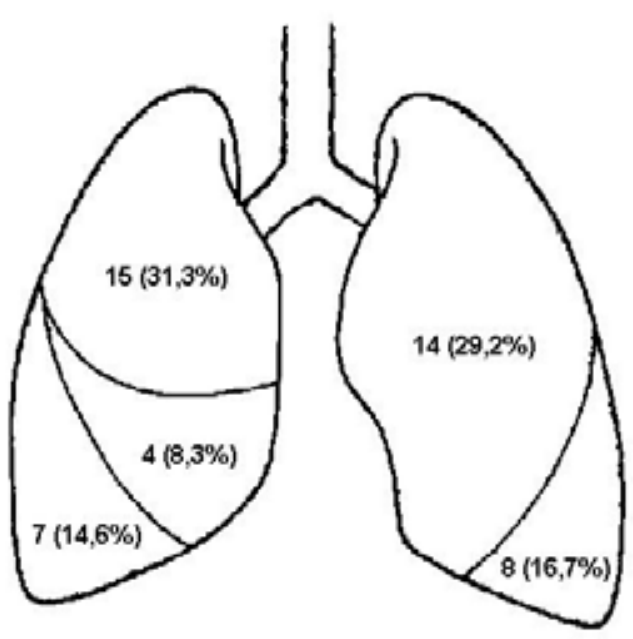

Mynd 1. Staðsetning æxla í lungum, sem voru fjarlægð hjá 44 sjúklingum sem gengust undir 47 fleyg- eða geiraskurði við lungnakrabbameini öðru en smáfrumukrabbmeini á Íslandi 1994-2008. Alls voru 48 æxli fjarlægð með skurðaðgerð. Gefinn er upp fjöldi æxla og prósentur í sviga.

Mynd Ásgeir Alexandersson. helstu gilda úr öndunarmælingum, sérstaklega fráblástur á fyrstu sekúndu útöndunar (forced expiratory volume in 1 second, FEV $V_{1}$ og heildarfráblástur (forced vital capacity, FVC). Einnig voru skráðar ástæðurnar sem skurðlæknir tiltók í aðgerðarlýsingu fyrir pví hvers vegna gerður var fleyg- eða geiraskurður í stað stærri aðgerðar.

Úr vefjasvörum meinafræðings (PAD-svar) voru skráð vefjagerð, proskunargráða æxlis, ${ }_{1}^{15}$ mesta pvermál æxlis og hvort skurðbrúnir voru án æxlisvaxtar. Við endurskoðun vefjasýna purfti að meta proskunargráðuna í sex tilfellum par sem gráðuna vantaði á upprunalega svarið. Í premur tilfellum breyttist gráðan við endurskoðun. Allir sjúklingarnir voru stigaðir samkvæmt TNMstigunarkerfinu (6. útgáfa) ${ }^{16}$ og miðast niðurstöður við upplýsingar sem lágu fyrir eftir vefjaskoðun sýnis úr aðgerð (pTNM). Stigun fyrir aðgerð (cTNM-stigun) var ekki stöðluð og var pví ekki skráð sérstaklega en fólst aðallega í röntgenmyndatöku af lungum og TS af brjóst- og kviðarholi. Beinaskann og TS af höfði voru gerð ef einkenni póttu gefa tilefni til. Einnig var gerð berkjuspeglun hjá 28 sjúklingum og ástunga á æxli í gegnum brjósthol í 20 tilfellum. Einn sjúklingur fór í miðmætisspeglun.

Aðgerðirnar framkvæmdu fimm skurðlæknar og framkvæmdi hver peirra á bilinu 4-19 aðgerðir. Sjúklingar voru svæfðir með tvíopa berkjurennu og pað lunga fellt saman sem gerð var aðgerð á. Aðgerðirnar voru yfirleitt framkvæmdar með fremri $(55,3 \%)$ eða aftari (42,6\%) hliðarskurði og æxlið fjarlægt með heftibyssu. Í tveimur tilfellum var reynd aðgerð með brjóstholssjá en í báðum tilvikum purfti að breyta yfir í opna aðgerð. Hjá einum sjúklingi var aðgerðin gerð í gegnum bringubeinsskurð og í sömu aðgerð gerð kransæðahjáveituaðgerð. Í lok aðgerðanna var komið fyrir einum eða tveimur brjóstholskerum sem hafðir voru í nokkra daga (miðgildi 3, bil 1-21).

Flestir sjúklinganna dvöldu á vöknunardeild í fjórar til sex klukkustundir eftir aðgerð (63,8\%). Í 17 tilfellum (36,2\%) purftu sjúklingar að liggja á gjörgæslu vegna vandamála sem upp komu í aðgerð eða til eftirlits, en 13 (76,5\%) peirra dvöldu par aðeins eina nótt.

Afdrif sjúklinganna voru könnuð með upplýsingum úr pjóðskrá par sem meðal annars fengust upplýsingar um hvort sjúklingarnir væru lífs eða liðnir pann 10. janúar 2010. Meðaleftirfylgni var 55 mánuðir (bil 0,2-13,7 ár). Skurðdauði (operative mortality) var skilgreindur sem andlát innan 30 daga frá aðgerð en einnig var kannað hversu margir höfðu látist innan 90 daga frá aðgerð. Tölvuforritin Excel og $\mathrm{R}$ voru notuð við tölfræðiúrvinnslu. Heildarlífshorfur (overall survival) voru reiknaðar með aðferð Kaplan-Meier. Kí-kvaðrat, Fisher exact-próf og t-próf voru notuð til að bera saman tímabil og hópa. Lífshorfur voru bornar saman með log-rank prófi og miðast marktækni við p-gildi $<0,05$.

Öll tilskilin leyfi frá Persónuvernd, Vísindasiðanefnd og framkvæmdastjóra lækninga á Landspítala lágu fyrir ádur en rannsóknin hófst.

\section{Niðurstöður}

Af 47 aðgerðum voru 42 fleygskurðir $(89,4 \%)$ og fimm geiraskurðir (10,6\%), en prír sjúklingar gengust undir tvær aðgerðir. Annar sjúklingur greindist með tvö frumæxli sem voru fjarlægð í sömu aðgerð og voru pví 48 æxli fjarlægð í heildina. Rúmlega helmingur aðgerðanna (55,3\%) var framkvæmdur á konum og var meðalaldur 


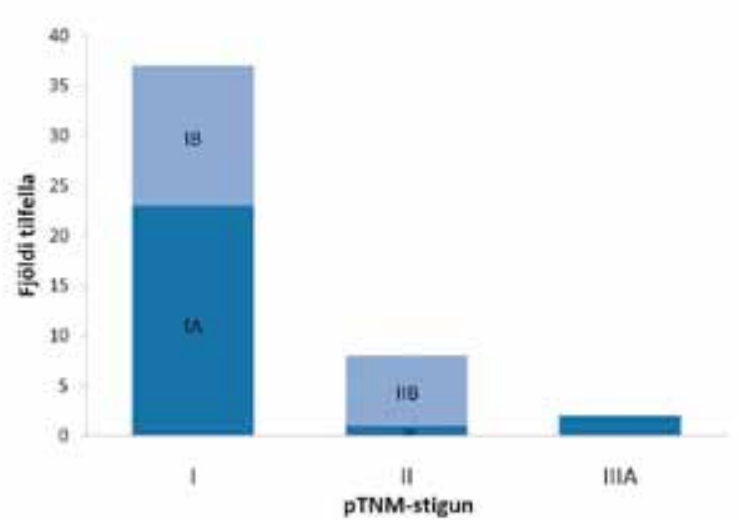

Mynd 2. TNM-stigun tilfella eftir aðgerð hjá 44 sjúklingum sem gengust undir 47 fleyg- eða geiraskurði við lungnakrabbameini öðru en smáfrumukrabbameini á Íslandi 1994-2008.

sjúklinga 69,1 \pm 9,9 ár (bil 43-84).

Samkvæmt upplýsingum úr Krabbameinsskrá voru á pessum 15 árum 1568 nýgreind lungnakrabbamein ÖES. Hlutfall fleyg- og geiraskurða af heildarfjölda greindra tilfella var 3,0\% fyrir allt tímabilið og breyttist ekki marktækt milli fimm ára tímabila $(4,0 \%$ 1994-1998, 2,4\% 1999-2003 og 2,8\% 2004-2008, p=0,31).

Ástand sjúklinga fyrir aðgerð má sjá í töflu I. Allir nema einn höfðu sögu um reykingar, 53,2\% höfðu reykt innan fimm ára fyrir aðgerð og fjöldi pakkaára var að meðaltali 42,9. Rúmlega helmingur (55,3\%) hafði pekktan kransæðasjúkdóm og 40,4\% langvinna lungnateppu. $\mathrm{FEV}_{1}$ án berkjuvíkkandi lyfjagjafar var að meðaltali 2,1 \pm 0,7 lítrar. Um priðjungur sjúklinga (31,9\%) var metinn í ASA-flokk 2 og 61,7\% í ASA-flokk 3, en meðal ASA-skor fyrir allan hópinn var 2,6.

Alls greindust 18 sjúklingar $(38,3 \%)$ fyrir tilviljun vegna myndrannsókna sem gerðar höfðu verið vegna annarra sjúkdóma. Aðrir höfðu einkenni og var hósti algengastur (58,6\%), oftast með uppgangi, en einn sjúklingur hafði blóðhósta. Önnur algeng einkenni voru mæði $(51,7 \%)$, lungnabólga $(37,9 \%)$ og hiti $(34,5 \%)$. Einkenni eins og brjóstverkur $(n=6)$, megrun $(n=4)$ og nætursviti $(n=3)$ voru sjaldgæfari.

Berkjuspeglun var framkvæmd hjá 59,6\% sjúklinga en berkjuspeglun gaf vefjagreiningu í aðeins einu tilfelli. Ástunga með TS var gerð hjá 42,6\% sjúklinga og fékkst vefjagreining í tveimur priðju ástunga (65,0\%). Hjá 70,2\% sjúklinga lá vefjagreining ekki fyrir áður en aðgerð var framkvæmd. Ein miðmætisspeglun var framkvæmd fyrir aðgerð og reyndust miðmætiseitlar eðlilegir.

Aðgerðartími (húð til húðar) var að meðaltali 83 mínútur (bil 30131) og blæðing í aðgerð $260 \mathrm{ml}$ (bil 100-650). Í sex tilfellum (12,8\%) var tekið sýni úr miðmætis- eða lungnarótareitlum og greindist æxlisvöxtur í helmingi peirra. Frystiskurðarsýni sem tekið var í aðgerð var skoðað af meinafræðingi í 24 tilfellum (51,1\%).

Algengasta ástæðan sem skurðlæknir gaf upp í aðgerðarlýsingu fyrir pví að framkvæma fleyg- eða geiraskurð í stað stærri aðgerðar var skert lungnastarfsemi ( $n=16,34 \%)$. I 25,5\% tilfella $(\mathrm{n}=12)$ voru aðrir undirliggjandi sjúkdómar nefndir, oftast hjartaog æðasjúkdómar (n=6), og í 21,3\% tilfella $(n=10)$ var hár aldur nefndur. Tvisvar var talið erfitt tæknilega að framkvæma blaðnám. Stundum voru nefndar fleiri en ein ástæða í aðgerðarlýsingunni en í 46,8\% tilfella (n=22) vantaði upplýsingar um ástæðurnar.
Tafla II. Fylgikvillar eftir aðgerð hjá 44 sjúklingum sem gengust undir 47 fleyg- eđa geiraskurði við lungnakrabbameini öđru en smáfrumukrabbameini á Íslandi 1994-2008. Sjúklingar geta haft fleiri en einn fylgikvilla. Gefinn er upp fjöldi tilfella og prósentur í sviga. Prósentur miðast við 47 tilfelli.

\begin{tabular}{lc}
\hline Fylgikvillar & $\boldsymbol{n}(\%)$ \\
\hline Minniháttar fylgikvillar & $\mathbf{1 8}(\mathbf{3 8 , 3 )}$ \\
\hline Lungnabólga & $7(14,9)$ \\
\hline Langvarandi loftleki $>7$ dagar) & $6(12,8)$ \\
\hline Pvagfærasýking & $5(10,6)$ \\
\hline Blæðing í aðgerð >500 ml & $4(8,7)$ \\
\hline Sárasýking & $2(4,3)$ \\
\hline Gáttatif & $1(2,1)$ \\
\hline Sýking í slagæðalegg & $1(2,1)$ \\
\hline Hjartabilun & $1(2,1)$ \\
\hline Alvarlegir fylgikvillar & $\mathbf{2 ( 4 , 3 )}$ \\
\hline Hjartadrep & $1(2,1)$ \\
\hline Heilablóðfall & $1(2,1)$ \\
\hline Látnir & $1(2,1)$ \\
\hline$<30$ daga & 0 \\
\hline$<90$ daga & \\
\hline
\end{tabular}

Flest æxlin, eða 66,7\%, voru kirtilmyndandi krabbamein en $22,9 \%$ voru flögupekjukrabbamein, prjú voru blanda af pessum tveimur og tvö reyndust stórfrumukrabbamein. Tæplega helmingur æxlanna, eða 43,8\%, voru illa proskuð, 37,5\% voru meðalvel proskuð og 16,7\% voru vel proskuð, en eitt æxli var óproskað. Meðalstærð æxlanna var 2,3 $\pm 1,1 \mathrm{~cm}$ og var minnsta æxlið $0,8 \mathrm{~cm}$ en pað stærsta 5,0 cm. Æxlisvöxtur fannst í skurðbrún í níu $(18,8 \%)$ tilfellum. Staðsetningar æxlanna eru sýndar á mynd 1. Flest voru staðsett í efri blöðum $(60,4 \%)$ en $31,3 \%$ í peim neðri og voru 26 í hægra lunga en 22 í pví vinstra $(\mathrm{p}=0,91)$.

Stigun (pTNM) má sjá á mynd 2. Flest tilfelli (78,7\%) reyndust vera á stigi I, en $48,9 \%$ voru á stigi IA og $29,8 \%$ á stigi IB. Færri voru á stigi II $(17,0 \%)$, en $2,1 \%$ voru á stigi IIA og $14,9 \%$ á stigi IIB. Tvö tilfelli reyndust vera á stigi IIIA.

Fylgikvillar eftir aðgerðirnar eru sýndir í töflu II. Alls fengu 18 sjúklingar (38,3\%) minniháttar fylgikvilla og var lungnabólga algengust (14,9\%). Pví næst komu langvarandi loftleki $(12,8 \%)$, pvagfærasýking (10,6\%) og blæðing yfir $500 \mathrm{ml}$ í aðgerð (8,7\%). Tveir fengu alvarlegan fylgikvilla par sem einn sjúklingur fékk hjartadrep og annar heilablóðfall. Enginn purfti enduraðgerð í tengslum við upprunalegu aðgerðina. Miðgildi legutíma var níu dagar, eða frá fjórum í 24 daga.

Flestir sjúklinganna dvöldu á vöknun eftir aðgerðina en 36,2\% purftu að leggjast inn á gjörgæslu yfir minnst eina nótt. Af peim lágu 13 (76,5\%) yfir eina nótt en lengst lá sjúklingur á gjörgæslu í sjö daga. Tveir sjúklingar voru fluttir á gjörgæslu í öndunarvél og voru pví ekki vaktir á skurðstofu. Annar peirra hafði farið í kransæðahjáveituaðgerð í sömu aðgerð. Enginn sjúklingur lést innan 30 daga en einn innan 90 daga frá aðgerð. Var dánarorsök hans rakin til fylgikvilla eftir aðgerð við vélindakrabbameini.

Fjórir fengu geislameðferð eftir aðgerð, tveir vegna pess að eitlar sem teknir voru við aðgerð reyndust innihalda meinvörp og tveir vegna vaxtar í skurðbrún. Einn sjúklingur hafði fengið lyfjameðferð 
Tafla III. Samanburður á niðurstöđum pessarar rannsóknar hjá 44 sjúklingum sem gengust undir 47 fleyg- eða geiraskurði við lungnakrabbameini öðru en smáfrumukrabbameini á Íslandi 1994-2008, og rannsóknar sem skoðaði 213 sjúklinga sem gengust undir blaðnám vegna sama sjúkdóms á Íslandi 19992008. ${ }^{11,12}$ Gefinn er upp fjöldi tilfella og prósentur í sviga, nema fyrir meðaltöl og heildarlífshorfur. Prósentur fyrir fleyg- og geiraskurði miðast við 47 tilfelli.

\begin{tabular}{|c|c|c|c|}
\hline & $\begin{array}{l}\text { Fleyg- og geiraskurðir } \\
\text { (Pessi rannsókn) }\end{array}$ & Blaðnám & P-gildi \\
\hline Tímabil & $1994-2008$ & $1999-2008$ & \\
\hline Fjöldi tilfella & 47 & 213 & \\
\hline Hlutfall á stigi I & $37(78,7)$ & $127(59,6)$ & $<0,02$ \\
\hline Meðalaldur (ár) & 69,1 & 66,9 & 0,17 \\
\hline Meðalstærð æxla (cm) & 2,3 & 3,7 & $<0,001$ \\
\hline Meðal ASA-skor & 2,6 & 2,6 & 0,74 \\
\hline Kransæðasjúkdómur & $26(55,3)$ & $55(25,8)$ & $<0,001$ \\
\hline Langvinn lungnateppa & $19(40,4)$ & $60(28,2)$ & 0,12 \\
\hline Meðalaðgerðartími (mín) & 83 & 128 & $<0,001$ \\
\hline Meðalblæðing í aðgerð (ml) & 260 & 580 & $<0,001$ \\
\hline Alvarlegir fylgikvillar & $2(4,3)$ & $16(7,5)$ & 0,54 \\
\hline $\begin{array}{l}\text { Látnir <30 daga } \\
\text { (skurðdauði) }\end{array}$ & 0 & 0 & \\
\hline Heildarlífshorfur & & & 0,93 \\
\hline 1 árs & $85,1 \%$ & $82,7 \%$ & \\
\hline 5 ára & $40,9 \%$ & $45,1 \%$ & \\
\hline
\end{tabular}

fyrir aðgerð en hann var greindur með brjóstakrabbamein og var talið fyrir aðgerð að um meinvörp væri að ræða í lunganu. Sami einstaklingur fékk einnig lyfjameðferð eftir aðgerð.

Við eftirlit pann 10. janúar 2010 reyndust 29 sjúklingar af 44 látnir en 15 voru á lífi. Á mynd 3 sjást heildarlífshorfur alls sjúklingahópsins par sem eins, priggja og fimm ára lífshorfur voru $85,1 \%, 64,9 \%$ og 40,9\%. Lífshorfur sjúklinga á stigi I voru $89,2 \%$, $74,6 \%$ og $43,5 \%$ (eins, priggja og fimm ára) en ekki var marktækur munur á lífshorfum hjá pessum hópi miðað við pá sem ekki voru á stigi I ( $\mathrm{p}=0,28$, log-rank próf).

Tafla III sýnir samanburð á helstu niðurstöðum pessarar rannsóknar sem náði til 47 fleyg- og geiraskurðaðgerða 19942008, og tveggja rannsókna par sem kannaður var árangur blaðnámsaðgerða hjá 213 sjúklingum með lungnakrabbamein ÖES á Íslandi 1999-2008. ${ }^{11-12}$ Marktækur munur reyndist á hlutfalli tilfella á stigi I, meðalstærð æxla, aðgerðartíma og blæðingu í aðgerð, fleygog geiraskurðum í hag. Hlutfall sjúklinga með kransæðasjúkdóm reyndist hins vegar marktækt lægra hjá sjúklingum sem fóru í blaðnám. Aðrir pættir náðu ekki marktækni, par með talinn meðalaldur, heildarlífshorfur, tíðni alvarlegra fylgikvilla og hlutfall sjúklinga með langvinna lungnateppu.

\section{Umræða}

Pessi rannsókn sýnir að fimm ára lífshorfur eftir fleyg- eða geiraskurð á Íslandi eru góðar (40,9\%) og nokkuð sambærilegar við árangur eftir blaðnám $(45,1 \%) .{ }^{11}{ }^{12}$ Tíðni skurðdauða og alvarlegra fylgikvilla eftir fleyg- og geiraskurði er lág og ekki reyndist marktækur munur á pessum páttum borið saman við fyrrgreindu rannsóknirnar á blaðnámi. ${ }^{11,12}$ Skurðdauði var enginn í báðum rannsóknum, sem verður að teljast góður árangur. Pegar tíðni fylgikvilla eftir fleyg- og geiraskurði er borin saman við lungnabrottnámsaðgerðir á Íslandi $1988-2007^{13}$ er munurinn meiri og er pað í samræmi við erlendar rannsóknir. ${ }^{17,} 19$ Pannig reyndist tíðni alvarlegra fylgikvilla eftir lungnabrottnám 15,6\% og skurðdauði 3,9\%, enda flestir pessara sjúklinga með miðlæg og stór æxli og aðeins $15,8 \%$ sjúklinga á stigi I. ${ }^{13}$

Fleiri sjúklingar greindust með sjúkdóm á stigi I eftir fleygeða geiraskurð en eftir blaðnám ${ }^{11,12}(\mathrm{p}<0,02)$ sem gæti átt pátt í góðum árangri hvað lífshorfur snertir. Eitlasýni voru ekki tekin í 87,2\% fleyg- og geiraskurðaðgerða hér á landi og aðeins ein miðmætisspeglun var framkvæmd fyrir aðgerð. Pví má leiða líkur að pví að hluti sjúklingahópsins hafi verið of lágt stigaður, bæði fyrir og eftir aðgerðina. Til pess að bæta stigun pyrfti að framkvæma fleiri miðmætisspeglanir en rannsóknir sýna að petta er örugg aðgerð sem hægt er að framkvæma í sömu svæfingu og brottnám lungnaæxlisins. ${ }^{20}$ Sýnatökur úr eitlum í aðgerð myndu einnig bæta stigunina en slíkar sýnatökur eru nú fastur hluti pessara aðgerða á Landspítala. Í erlendum rannsóknum er gjarnan borinn saman árangur fleyg- og geiraskurða og blaðnáms við sjúkdómi á stigi I. Fimm ára lífshorfur í pessum rannsóknum hafa verið á bilinu 33-69\% $\%$ og okkar niðurstöður (43,5\%) pví í neðri hluta pessa bils. Skýringin á pessum mun gæti legið í pví að í flestum erlendu rannsóknunum voru eitlar rannsakaðir mun ítarlegar og stigun pví áreiðanlegri. 5,9

Marktækt fleiri sjúklingar í pessari rannsókn höfðu kransæðasjúkdóm $(\mathrm{p}<0,001)$ í samanburði við sjúklingana í áðurnefndu rannsóknunum á blaðnámi. ${ }^{11}{ }^{12}$ Auk pess voru sjúklingar í pessari rannsókn aðeins eldri og höfðu oftar langvinna lungnateppu pótt hvorugur pessara pátta næði marktækni. Að framanskráðu hefði mátt búast við meiri mun í fimm ára lífshorfum milli hópa. Hafa skal pó í huga að ekki var leiðrétt fyrir aldri í samanburðinum en búast má við hærri tíðni kransæðasjúkdóms í eldri sjúklingum. Sjúklingar í blaðnámshópi voru líka á marktækt hærri TNM-stigum sem hefur áhrif á horfur.

Fáir fylgikvillar og sambærilegar lífshorfur vekja upp spurningar um hvort verið sé að velja í fleyg- eða geiraskurð pá sem hefðu getað polað blaðnám. Skert lungnastarfsemi og aðrir undirliggjandi sjúkdómar, oftast hjarta- og æðasjúkdómar, voru helstu ástæður pess að skurðlæknir valdi að gera ekki blaðnám. Nákvæmari rannsóknir á lungna- og hjartastarfsemi fyrir aðgerð gætu gefið mikilvægar vísbendingar um möguleika á blaðnámi eða hvort fleyg- eða geiraskurður sé betri valkostur. ${ }^{21}$ Í sumum tilfellanna var erfitt að vita nákvæmlega hvað lá að baki peirri ákvörðun að framkvæma fleyg- eða geiraskurð, enda rannsóknin afturskyggn og skráningu í aðgerðarlýsingu stundum ábótavant. Ástæður voru pó betur skráðar á síðasta fimm ára tímabilinu, eða í 70\% tilfella miðað við 43\% fyrstu 10 árin. Skráning virðist pví hafa batnað með árunum.

Með fleyg- eða geiraskurði er valin tæknilega einfaldari aðgerð en blaðnám. Meira er varðveitt af lungnavef og aðgerðartími styttur um 45 mínútur samkvæmt okkar gögnum. ${ }^{11,12}$ Fleyg- og geiraskurðir hafa verið taldir síðri aðgerðir við lungnakrabbameini, aðallega vegna aukinnar tíðni endurkomins krabbameins. ${ }^{5}$ Nýlegar rannsóknir á smáum æxlum $(<2 \mathrm{~cm})$, meðal annars frá Japan, benda pó til pess að pegar um lítil útlæg æxli er að ræða purfi ekki að gera 


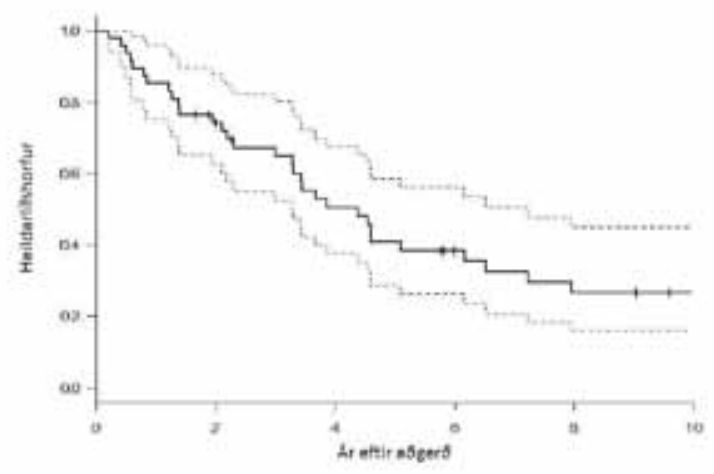

Mynd 3. Heildarliffshorfur (Kaplan-Meier) 44 sjúklinga sem gengust undir 47 fleygeða geiraskurði við lungnakrabbameini öðru en smáfrumukrabbameini á Íslandi 19942008. Brotalínur sýna 95\% öryggisbil.

blaðnám og að heildarlífshorfur séu sambærilegar pegar til langs tíma er litið. $6,7,9$

Í pessari rannsókn voru um 10\% aðgerða geiraskurðir en $90 \%$ fleygskurðir sem er lægra hlutfall geiraskurða en í sambærilegum rannsóknum erlendis. ${ }^{5}$, 6, 9, 22 Vegna fæðar sjúklinga reyndist ekki unnt að bera saman árangur geira- og fleygskurðar. Stærri rannsóknir hafa sýnt að tíðni endurkomins krabbameins og lífshorfur eru betri eftir geiraskurði en fleygskurði. 5, 6, 22 Er skýringin talin vera sú að við geiraskurði eru skurðbrúnir víðari og fleiri eitlar fjarlægðir, enda reynt að fjarlægja geirann í heild sinni. ${ }^{6}$, 7 Geiraskurðirnir pykja hins vegar tæknilega erfiðari ${ }^{7}$ og eiga pví síður við hjá sjúklingum með flókna undirliggjandi sjúkdóma.

Enn er blaðnám talin besta aðgerðin við lungnakrabbameini og henni er pví beitt í langflestum tilvikum. ${ }^{2}$ Í pessari rannsókn var fleyg- eða geiraskurður framkvæmdur á 3,0\% nýgreindra lungnakrabbameina ÖES sem er svipað og í stórri bandarískri rannsókn par sem hlutfallið var 4,3\%. ${ }^{4}$ Á næstu árum gæti vægi umfangsminni aðgerða pó átt eftir að aukast par sem sífellt fleiri lítil og útlæg lungnakrabbamein greinast vegna framfara í myndrannsóknum. ${ }^{17}$ Með pví að framkvæma minni aðgerð aukast líkur á að sjúklingur poli aðra aðgerð greinist hann með nýtt frumæxli. ${ }^{5,7,22}$

Allar aðgerðirnar voru framkvæmdar í gegnum brjóstholsskurð og var í rúmum helmingi tilfella beitt fremri/hliðarskurði sem er minni að umfangi en hefðbundinn brjóstholsskurður. Í tveimur tilfellum var upphaflega reynt að framkvæma aðgerðina með brjóstholssjá (VATS) en hjá báðum sjúklingunum purfti að breyta yfir í hefðbundna opna aðgerð. Ástæðan í öðru tilfellinu var að æxlið fannst ekki og í hinu tilfellinu reyndist tæknilega erfitt að fjarlægja æxlið. Erlendar rannsóknir hafa sýnt að lífshorfur og tíðni endurtekins sjúkdóms eftir aðgerð með brjóstholssjá eru sambærilegar og eftir hefðbundna opna aðgerð, auk pess eru fylgikvillar og verkir eftir aðgerð taldir minni. ${ }^{2,23}$ Pessar rannsóknir eru pó fæstar slembaðar og pví ekki hægt að útiloka skekkju í vali á sjúklingum. ${ }^{24}$

Vefjagerð lá ekki fyrir áður en aðgerð var framkvæmd í rúmlega tveimur priðju tilfella sem verður að teljast hátt hlutfall. Í einungis einu tilfelli fékkst greining fyrir aðgerð með berkjuspeglun en mun oftar með ástungu á brjóstholi með aðstoð TS, eða í 65\% ástunga. Langflest æxlanna voru staðsett utarlega í lunganu en slík staðsetning er forsenda pess að hægt sé að framkvæma fleygeða geiraskurð. Petta skýrir einnig hátt hlutfall kirtilmyndandi krabbameina $(66,7 \%)$ en pau eru oftar staðsett útlægt í lunganu en flögupekjukrabbamein. ${ }^{25}$

Krabbameinslyfjameðferð eftir aðgerð var einungis beitt í einu tilfelli. Í dag er viðbótarmeðferð í formi krabbameinslyfja yfirleitt beitt hjá sjúklingum á stigi II og IIIA, enda hefur verið sýnt fram á bættan langtímaárangur við slíka meðferð. ${ }^{2,3}$ Fjórir sjúklingar fengu geislameðferð eftir skurðaðgerðina en slík meðferð er ekki talin hafa áhrif á langtímaárangur. ${ }^{2,3}$

Samantekið er tíðni fylgikvilla eftir fleyg- og geiraskurði lág á Íslandi og virðist svipuð og eftir blaðnám. Lífshorfur eru einnig sambærilegar og eftir blaðnám en marktækt fleiri sjúklingar greindust með sjúkdóm á stigi I eftir fleyg- eða geiraskurð. Lág tíðni fylgikvilla eftir fleyg- og geiraskurði kom á óvart, par sem fleiri sjúklingar höfðu undirliggjandi hjarta- eða lungnasjúkdóma. Ljóst er að bæta parf stigun pessara sjúklinga með sýnatöku úr eitlum.

\section{Pakkir}

Gunnhildur Jóhannsdóttir skrifstofustjóri fær pakkir fyrir aðstoð við leit að sjúkraskrám og Húnbogi Porsteinsson fyrir yfirlestur og góðar ábendingar. Rannsóknin var styrkt af Vísindasjóði Landspítala, Styrktar- og verðlaunasjóði Bents Scheving Thorsteinsson og Nýsköpunarsjóði námsmanna.

\section{Heimildir}

1. Jónasson JG, Tryggvadóttir L (ritsti). Krabbamein á Íslandi - Upplýsingar úr Krabbameinsskrá fyrir tímabilið 19572006. Krabbameinsfélagið, Reykjavík 2008.

2. Scott WJ, Howington J, Feigenberg S, Movsas B, Pisters K. Treatment of non-small cell lung cancer stage I and stage II: ACCP evidence-based clinical practice guidelines (2nd edition). Chest 2007; 132(3 Suppl): 234S-42S

3. Robinson LA, Ruckdeschel JC, Wagner H, Jr., Stevens CW. Treatment of non-small cell lung cancer-stage IIIA: ACCP evidence-based clinical practice guidelines (2nd edition). Chest 2007; 132(3 Suppl): 243S-65S.

4. Little AG, Rusch VW, Bonner JA, et al. Patterns of surgical care of lung cancer patients. Ann Thorac Surg 2005; 80: 2051-6; discussion 6 .

5. Ginsberg RJ, Rubinstein LV. Randomized trial of lobectomy versus limited resection for T1 N0 non-small cell lung cancer. Lung Cancer Study Group. Ann Thorac Surg 1995; 60: 615-22; discussion 622-3.

6. Rami-Porta R, Tsuboi M. Sublobar resection for lung cancer. Eur Respir J 2009; 33: 426-35.
7. Okada M, Koike T, Higashiyama M, Yamato $\mathrm{Y}$, Kodama K, Tsubota N. Radical sublobar resection for small-sized non-small cell lung cancer: a multicenter study. J Thorac Cardiovasc Surg 2006; 132: 769-75.

8. Detterbeck FC, Jantz MA, Wallace M, Vansteenkiste J, Silvestri GA. Invasive mediastinal staging of lung cancer: ACCP evidence-based clinical practice guidelines (2nd edition). Chest 2007; 132(3 Suppl): 202S-20S.

9. El-Sherif A, Gooding WE, Santos R, et al. Outcomes of sublobar resection versus lobectomy for stage I non-small cell lung cancer: a 13-year analysis. Ann Thorac Surg 2006; 82: 408-15; discussion 415-6.

10. Nakata M, Sawada S, Saeki H, et al. Prospective study of thoracoscopic limited resection for ground-glass opacity selected by computed tomography. Ann Thorac Surg 2003; 75: 1601-5; discussion 165-6.

11. Óskarsdóttir GN, Skúladóttir R, Ísaksson HJ, Jónsson S, Porsteinsson H, Guðbjartsson T. Forspárbættir lífshorfa eftir blaðnám við lungnakrabbameini á Íslandi 1999-2008. Læknablaðið 2010; 96: 251-7.
12. Skúladóttir R, Óskarsdóttir GN, Ísaksson HI, Jónsson S, Porsteinsson H, Guðbjartsson T. Fylgikvillar blaðnámsaðgerða við lungnakrabbameini á Íslandi 1999-2008. Læknablaðið 2010; 96: 243-9.

13. Porsteinsson $\mathrm{H}$, Jónsson $\mathrm{S}$, Alfreðsson $\mathrm{H}$, Ísaksson $\mathrm{HI}$ Guðbjartsson T. Árangur lungnabrottnámsaðgerða við lungnakrabbameini á Íslandi. Læknablaðið 2009; 95: 823-9.

14. Dripps RD, Lamont A, Eckenhoff JE. The role of anesthesia in surgical mortality. JAMA 1961; 178: 261-6.

15. Travis WD, Brambilla E, Muller-Hermelink HK, Harris CC (Eds.). World Health Organization Classification of Tumours. Pathology and Genetics of Tumours of the Lung, Pleura, Thymus and Heart. IARC Press, Lyon 2004.

16. Mountain CF. Revisions in the International System for Staging Lung Cancer. Chest 1997; 111: 1710-7.

17. Watanabe S, Asamura H, Suzuki K, Tsuchiya R. Recent results of postoperative mortality for surgical resections in lung cancer. Ann Thorac Surg 2004; 78: 999-1002; discussion 1002-3. 
18. Gudbjartsson T, Gyllstedt E, Pikwer A, Jonsson P. Early surgical results after pneumonectomy for non-small cell lung cancer are not affected by preoperative radiotherapy and chemotherapy. Ann Thorac Surg 2008; 86: 376-82.

19. Myrdal G, Gustafsson G, Lambe M, Horte LG, Stahle E. Outcome after lung cancer surgery. Factors predicting early mortality and major morbidity. Eur J Cardiothorac Surg 2001; 20: 694-9.

20. Park BJ, Flores R, Downey RJ, Bains MS, Rusch VW. Management of major hemorrhage during mediastinoscopy. J Thorac Cardiovasc Surg 2003; 126: 726-31.
21. Colice GL, Shafazand S, Griffin JP, Keenan R, Bolliger CT. Physiologic evaluation of the patient with lung cancer being considered for resectional surgery: ACCP evidenced-based clinical practice guidelines (2nd edition). Chest 2007; 132(3 Suppl): 161S-77S.

22. Sienel W, Dango S, Kirschbaum A, et al. Sublobar resections in stage IA non-small cell lung cancer: segmentectomies result in significantly better cancerrelated survival than wedge resections. Eur J Cardiothorac Surg 2008; 33: 728-34.

23. Endo C, Sagawa M, Sakurada A, Sato M, Kondo T, Fujimura S. Surgical treatment of stage I non-small cell lung carcinoma. Ann Thorac Cardiovasc Surg 2003; 9: 283-9.
24. West $D$, Rashid $S$, Dunning J. Does video-assisted thoracoscopic lobectomy produce equal cancer clearance compared to open lobectomy for non-small cell carcinoma of the lung? Interact Cardiovasc Thorac Surg 2007; 6: 110-6.

25. Spiro SG, Gould MK, Colice GL. Initial evaluation of the patient with lung cancer: symptoms, signs, laboratory tests, and paraneoplastic syndromes: ACCP evidencedbased clinical practice guidelines (2nd edition). Chest 2007; 132(3 Suppl): 149S-60S.

\section{ENGLISH SUMMARY}

\section{Sublobar Resection for Non-Small Cell Lung Cancer in Iceland}

Alexandersson A, Jonsson S, Isaksson HJ, Gudbjartsson T

Introduction: A sublobar resection is performed on patients with non-small cell lung cancer (NSCLC) who are not candidates for a lobectomy due to reduced pulmonary function or comorbid disease. The aim of this study was to investigate the outcomes of these operations in lceland.

Material and methods: A retrospective study of all patients with NSCLC who underwent wedge resection or segmentectomy with curative intent during 1994-2008. Data on indication, pathological TNM-stage, complications and overall survival was analyzed. All histological samples were re-evaluated.

Results: Forty four patients underwent 42 wedge and 5 segmental resections (age 69.1 yrs, $55.3 \%$ female), with $38.3 \%$ of cases detected incidentally. The majority of patients (55.3\%) had a history of coronary artery disease and $40.4 \%$ had chronic obstructive pulmonary disease. Mean operative time was 83 minutes (range 30-131), mean intraoperative bleeding was $260 \mathrm{ml}$ (range 100-650) and median hospital stay was 9 days (range 4-24). Pneumonia (14.9\%) and prolonged air leakage (12.8\%) were the most common complications. Two patients had major complications and $36.2 \%$ stayed in the intensive care unit overnight. No deaths occurred within 30 days of surgery. Adenocarcinoma was the most common histological type (66.7\%). Most cases were stage IA/IB (78.7\%), $17.0 \%$ were stage IIA/IIB and $4.3 \%$ were stage IIIA. One and 5 year survival was $85.1 \%$ and $40.9 \%$ respectively.

Conclusion: In Iceland, both survival and complication rate after sublobar resection for NSCLC are comparable to results published for lobectomies, even though a higher percentage of patients have underlying cardiopulmonary disease.

Key words: sublobar resection, wedge resection, segmentectomy, NSCLC, complications, survival.

Correspondence: Tómas Guðbjartsson, tomasgud@landspitali.is 